\title{
John B. Thompson: \\ Merchants of Culture. \\ The Publishing Business in the Twenty-First Century. Cambridge: Polity. 2010.
}

\section{Stig Hjarvard}

MedieKultur 2011, 51, 172-175

Published by SMID | Society of Media researchers In Denmark | www.smid.dk The online version of this text can be found open access at www.mediekultur.dk

Most researchers and students of media and communication think of Cambridge professor John B. Thompson as a scholar of high theory concerning ideology, media and modernity. During the last decade, however, John B. Thompson has pursued a different line of research: extensive empirical studies of the publishing industry. His first book on the subject, Books in the Digital Age (Polity, 2005), was an in-depth study of academic and higher education publishing in Great Britain and the United States (see review here: http://ejc.sagepub.com/ content/21/3/409.full.pdf). In his most recent book, Merchants of Culture, he has moved out of the academic world of research monographs, journals and textbooks and into the much broader field of trade publishing - that is, the industry of fiction as well as non-fiction books aimed at general audiences.

His investigation of this industry is primarily based on approximately 280 qualitative interviews with a variety of people working in the publishing industry (editors, marketing directors, agents, retailers etc.) from the dominant corporations to the small independent publishers. In addition to reports concerning inside experiences from the industry, the book contains a wealth of factual information about ownership, publishing statistics etc. He deliberately limits his study to American and British publishing businesses, but considering their size and dominant position in the world market, this is still an impressive endeavour. The theoretical framework for his new book is quite similar to his earlier study on the academic publishing industry. Inspired by Bourdieu, the trade publishing industry is understood as a particular field dominated by a set of relational dynamics, which he refers to as 
"the logic of the field" (p. 11). Various forms of capital play a role in this field, but it is first and foremost two kinds of capital, economic and symbolic, that are at stake: selling books is simultaneously about earning money and acquiring symbolic recognition. Bourdieu's relational sociology works well as a general starting point, but John $\mathrm{B}$. Thompson is clearly not preoccupied with theory in this book. Instead, he guides the reader into the back offices of editors, marketers and book sellers who have all experienced profound changes due to industrial mergers, commercialisation and new technologies.

In the first part of the book, John B. Thompson traces the historical changes in the publishing industry from the 1960s and onwards, although transformations during the most recent couple of decades receive primary attention. Three major developments have changed the way books are produced and distributed: the growth of retail chains, the rise of literary agents and the emergence of publishing corporations. The traditional retail market of books consisted of small and individual bookstores in combination with department store sales, but gradually bookstores became bigger and moved to the shopping malls. Furthermore, the growth of retail chains like Barnes \& Nobles and Borders paved the way for superstores, and their ability to mass-market hardcover editions of new books across the nation created "the hardcover revolution". Before this, paperback editions had been responsible for a considerable share of profits, but in the 1980s and 1990s hardcover editions became the financial driving force. Literary agents are not an entirely new phenomenon, but their role has increased due to growing opportunities to exploit the rights associated with a book in larger markets. In the United States, the large corporations grew increasingly uninterested in publishing houses during the 1980s. During the previous decades, publishing houses had merged into larger ones and some of them had been taken over by big media corporations. But the expected industrial synergy between publishing and other media failed to appear and some American publishing houses were sold off to large European publishing houses like the German Bertelsmann. As John B. Thompson lucidly puts it: "For Wall Street, book publishing is not just old media, it is old, old media" (p. 111) and the profit margins are too small to be of interest to big firms that need to satisfy their shareholders. For a European publishing house, by contrast, a take-over of an American publishing house represents a promising way to expand business when further growth in the domestic market is no longer possible.

John B. Thompson devotes a lengthy chapter to "The Digital Revolution", but he seems very cautious not to overestimate the impact of digital technologies in general and the e-book in particular. The influence of technology does not derive from a single medium like the e-book or the digital technology itself, but from the structuring influence of a variety of technologies on the social process of book publishing. As he states: "A revolution has taken place in publishing and is continuing to take place, but it is a revolution in the process rather than a revolution in the product" (p. 321, emphasis in original). These changes involve the digitalisation of the workplace as well as marketing, sales and content delivery through digital media etc. For instance, the Amazon model has made the visibility, availability and 
sales of books less dependent on many of the existing intermediaries in the bookselling chain. Another long-term change may arise from the Internet bookstores' lowering of prices on e-books. Many publishers fear that this may change the public's perception of the actual costs involved in the production of a book. John B. Thompson is certainly not a technooptimist (or -pessimist for that matter), but cautiously reports how a new generation of e-books seems to have experienced rapid growth during the last couple of years. But his manuscript was probably finalised just before the real take-off in e-book sales in the United States and therefore the book is unable to consider this development.

What is the outcome, then, of all these diverging developments in the field of publishing? The book points to numerous commercial and cultural consequences. One significant phenomenon is the growing focus on "big books" in the trade. The immense success of books being recommended by Oprah Winfrey through her Oprah Winfrey Book Club or the frenzy accompanying the movie releases of Dan Brown's bestsellers The Da Vinci Code and Angels and Demons are good examples of the exploding sales expectations in the publishing industry. Bestseller lists have become an important yardstick not just for the retail stores but for the whole publishing cycle of manuscript acquisition, marketing and sales management. This has already influenced the diversity of books, but not in terms of availability. As John B. Thompson observes, it has become increasingly easy to publish books, but we should be concerned about the "diversity or otherwise of the books that are noticed, purchased and read" (p. 389, emphasis in original). The book market is concentrating on a small number of titles that sell better than ever, while the market for books selling more modestly is shrinking. A related problem is the "short-termism" of contemporary book publishing. The industry has traditionally been a long-term business that valued the gradual development of authors and the building of a solid backlist of books. Today, the long horizon has been replaced by a focus on how to boost the immediate revenue stream. One consequence is an impatience with new authors. Publishers are constantly looking for new creative talents and are willing to take risks, but if new writers do not work well, publishers quickly lose interest in supporting the writers' development.

With Merchants of Culture, John B. Thompson has written a very valuable book that is likely to become the standard reference on the Anglo-American publishing industry for many years to come. Readers looking for social theory or reflections on the role of new media may be disappointed because of the dominant focus on empirical circumstances and business considerations. This focus, however, is also the very strength of the book that delivers both an overview of general developments and details about the history of this particular - and neglected - media industry. Two actors in the publishing industry seem to deserve more analyses and reflection, however: the reviewer and the author. The study primarily looks at the industry from the point of view of the publishers, but the role of traditional cultural intermediaries like book reviewers does not receive much attention. John B. Thompson will probably say this is because of their shrinking influence, but a more thorough treatment of this dimension would nevertheless have shed light on the possible 
diminishing value of cultural capital. In general, Merchants of Culture is preoccupied with the role of economic capital and only to a lesser degree symbolic or cultural capital. Similarly, the real producers of the industry, the authors, do not play a significant role in John B. Thompson's account, and this may very well reflect his own observation that many authors feel frustrated and disconnected from the industry. However, it would have been highly interesting to learn more about this - paradoxical - isolated position of the key labour force in the publishing business. John B. Thompson's new book is a well-written and carefully balanced analysis of one of our important media industries. It is not only recommended to students of media and communication, but to anyone interested - and working - in the publishing industry.

Stig Hjarvard,

Professor, PhD

Department of Media, Cognition and Communication

University of Copenhagen, Denmark

stig@hum.ku.dk 